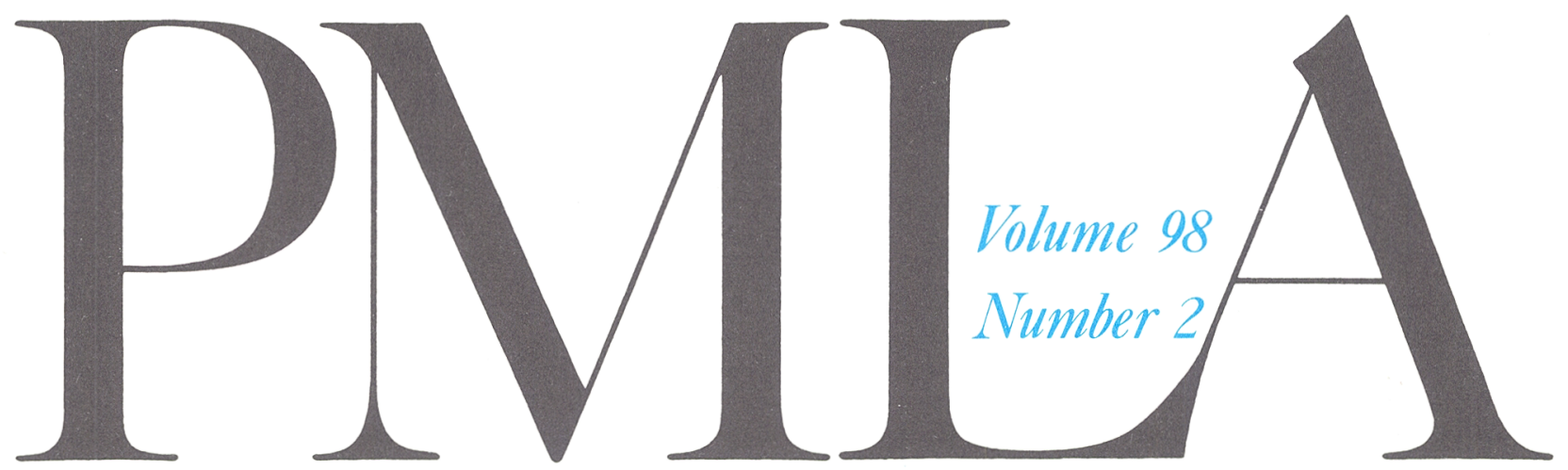

Publications of the

Modern Language Association

of America 


\section{TOMORROW'S EVE}

Villiers de l'Isle Adam. Translated and with an introduction by Robert Martin Adams.

This is the first English translation of a science-fiction fantasy written a century ago. Villiers' sardonic tale, set in late 19th-century America, adds a macabre twist to the old story of idealized love. "Tomorrow's Eve definitely deserves to be better known. Now it can be, thanks to Robert Adams's excellent translation. It is racy, humorous, colloquial, entirely right in tone and rhythm, and highly readable." - Paul de Man, Yale University. \$17.95

\section{PARADOXICAL RESOLUTIONS American Fiction since James Joyce}

Craig Hansen Werner. Werner traces Joyce's impact on classic contemporary novelists like Barth, Bellow, Ellison, Mailer, and Pynchon, and on experimental stylists like Barthelme, Federman, Sukenick, and Sorrentino. In addition he gives considerable space to Afro-American and women writers (Gaines, Baldwin, Kelley, Morrison, $\mathrm{O}$ 'Connor, Plath). "This is a frequently brilliant study of American fiction.... Werner's judgments are both profound and entertaining, his style clear and readable." - David Hayman, author of Ulysses: The Mechanics of Meaning. $\$ 18.95$

\section{FAULKNER'S SEARCH FOR A SOUTH}

Walter Taylor. This "inside biography" of Faulkner's intellectual and artistic development analyzes Faulkner's ambivalent commitment to the southern aristocracy and the conflict that commitment created in a writer who spent his entire career trying to unravel the moral tangle that had grown out of the institution of slavery. "Taylor's fresh approach transcends that body of Faulkner criticism which has rigidified under both the principles and the pieties of formalist criticism." - George E. Kent, University of Chicago. $\$ 18.50$

\section{REDISCOVERIES}

\section{Literature and Place in Illinois}

Robert C. Bray. Bray reclaims a nearly lost literary heritage in his re-evaluation of the literature about Illinois - from the early diaries and travel narratives of the pioneers to the great age of novel-writing and the beginnings of modernist poetry preceding World War I. "Bray's goal is to establish that a solid tradition of Illinois literature lay behind the twentieth-century achievements of Sandburg, Masters, Dreiser, Farrell, and the present generation of regional writers. His book is well focused, unusually well written, and often quite moving." - James Hurt, University of Illinois at Urbana-Champaign. \$16.95

UNIVERSITY OF ILLINOIS PRESS Urbana-Champaign Chicago London
We accept major credit cards. Phone toll free 800/638-3030. Maryland residents phone 301/824-7300. 


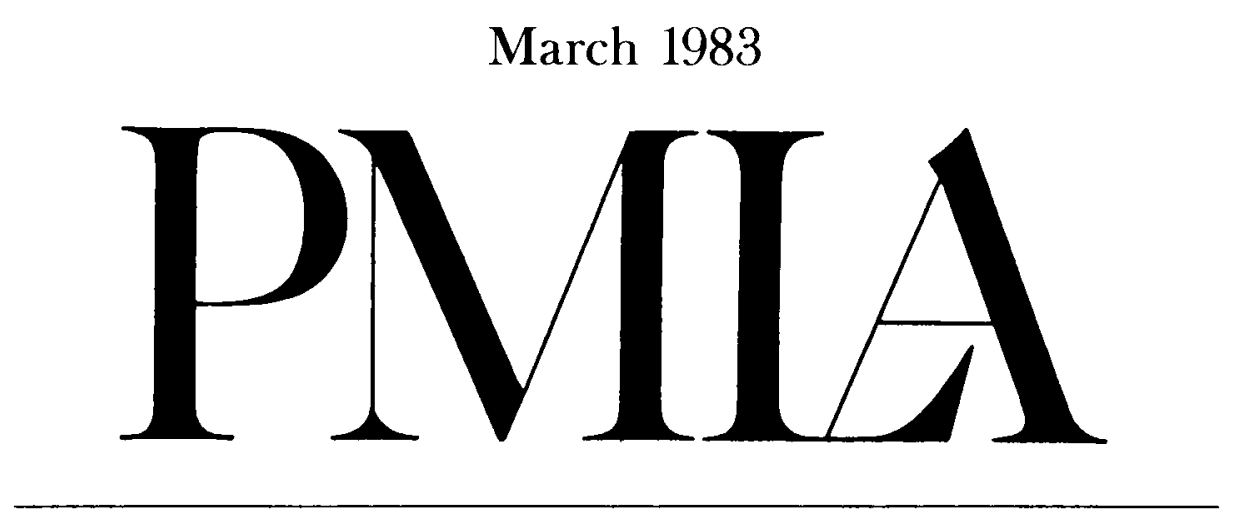

Publications of the
Modern Language Association of America

Volume 98

Number 2

PUBLISHED SIX TIMES A YEAR BY THE ASSOCIATION 


\title{
The Modern Language Association of America
}

ORGANIZED 1883

INCORPORATED 1900

\author{
OFFICERS FOR THE YEAR 1983 \\ President: Mary ANn Caws, Hunter College and Graduate Center, \\ City University of New York \\ First Vice-President: CaRolyn G. HeILBRUN, Columbia University \\ Executive Director: JoEl CONARRoE, University of Pennsylvania \\ Deputy Executive Director: HaNs RütIMANN
}

\section{EXECUTIVE COUNCIL}

For the term ending 31 December 1983

\section{Paul Fusseli \\ Rutgers University \\ BARBARA K. LEWALSKI \\ Harvard University \\ Gita MAY \\ Columbia University}

For the term ending 31 December 1985

Jonathan Culler

Cornell University

JUAN LóPEZ-MORILLAS

University of Texas, Austin

Catharine R. STimpson

Rutgers University
For the term ending 31 December 1984

SAndRa M. GilberT

University of California, Davis

A. WALTON LiTz

Princeton University

Aldo SCAGLIone

University of North Carolina, Chapel Hill

For the term ending 31 December 1986

Paul Hernadi

University of Iowa

Eva M. KusHNER

McGill University

ULRICH W. WEISSTEIN

Indiana University, Bloomington

TRUSTEES OF INVESTED FUNDS

GoRDON N. RAY

Guggenheim Foundation, Managing Trustee
C. WALLER BARRETT

Charlottesville, Virginia

ROBERT LUMIANSKY

American Council of Learned Societies

$P M L A$ (ISSN 0030-8129) is issued six times a year, in January, March, May, September, October, and November, by the Modern Language Association of America, 62 Fifth Avenue, New York, New York 10011. Membership is open to those persons who are professionally interested in the modern languages and literatures. Annual dues, which include subscription to $P M L A$, are based on members' salaries and are graduated as follows: student members, $\$ 10$; unemployed regular members, $\$ 10$; regular members (first year), $\$ 20$; regular members (salary under $\$ 12,000$ ), $\$ 25$; regular members (salary $\$ 12,000-\$ 15,000$ ), $\$ 30$; regular members (salary $\$ 15,000-\$ 20,000$ ), $\$ 35$; regular members (salary $\$ 20,000-\$ 25,000$ ), $\$ 40$; regular members (salary $\$ 25,000-\$ 30,000$ ), $\$ 45$; regular members (salary $\$ 30,000-\$ 35,000$ ), $\$ 50$; regular members (salary over $\$ 35,000$ ), $\$ 55$; joint members (with only one subscription to $P M L A$ ), add $\$ 10$ to dues category of higher-paid member; foreign members, same as regular members. Membership applications are available on request.

The subscription price of $P M L A$ for libraries and other institutions is $\$ 60$. A subscription including a bound volume at the end of the year is $\$ 150$, domestic and foreign. Agents deduct $10 \%$ as their fee. Single copies of the January, March, May, and October issues may be obtained for $\$ 7.50$ each; the November (Program) issue for $\$ 20$; the September (Directory) issue for $\$ 35$.

Issues for the current year are available from the MLA Member and Customer Services Office. Claims for undelivered issues will be honored if they are received within one year of the publication date; thereafter the single issue price will be charged.

For information about the availability of back issues, inquire of Kraus Reprint Co., Millwood, NY 10546; (914) 762-2200. Early and current volumes may be obtained on microfilm from University Microfilms, Ann Arbor, MI 48106. Purchase of current volumes on film is restricted to subscribers of the journal.

\section{OFFICE OF PUBLICATION AND EDITORIAL OFFICES} 62 Fifth Avenue, New York, NY 10011 Tel: 212 741-5588

All communications including notices of changes of address should be sent to the Member and Customer Services Office of the Association at 62 Fifth Avenue, New York, NY 10011. If a change of address also involves a change of institutional affiliation, that office should be informed of this fact at the same time.

Second-class postage paid at New York, NY, and at additional mailing office.

Copyright (C) 1983 by The Modern Language Association of America.

Library of Congress Catalog Card Number 12-32040.

POSTMASTER: Send address changes to Member and Customer Services Office, Modern Language Association of America, 62 Fifth Avenue, New York, NY 10011. 


\title{
Contents - March
}

Editor's Column . $. \quad . \quad . \quad . \quad . \quad . \quad . \quad . \quad . \quad$.

Milton, Paradise Regained, and Georgic. Anthony Low . .

\begin{abstract}
Although the question of genre has puzzled critics of Paradise Regained, the poem's structure, style, and spirit, as well as much of its imagery, are georgic. Like Vergil, Milton emphasizes incessant labor, constructive as opposed to destructive heroism, and quiet effort to build a flourishing civilization. In the Georgics as in the Bible, the right response to the curse of labor transforms it into a blessing. While epic glorifies war, georgic celebrates the arts of peace. In Paradise Lost, Adam and Eve enjoy a pastoral paradise of ease until they fall; then they and their descendants must earn their bread in a hard georgic world. In Paradise Regained, Satan variously attempts to pervert the generic mode of the Son's heroism. After a laborious struggle, the Son confirms himself in the role anticipated by Milton's opening metaphor: he raises a georgic garden in the world's "wast Wilderness." (AL)
\end{abstract}

\section{Theatrical Legitimation: Forms of French Patronage and Por-} traiture. Timothy Murray . . . . . . . .

\begin{abstract}
Seventeenth-century French patronage of the theater was an ideal means of political legitimation. While Louis XIII sporadically exercised patronage through royal decrees and attendance at comedies, the Cardinal de Richelieu, who better understood the theater's political benefits, actively influenced its technical aspects: the acting companies, the scripts, and the dramatic conventions and mechanics. The goal of Richelieu's patronage was the beholders' symbolic identification of the elements of refined theater with the genius of the cardinal underwriting them. The Jansenists' tracts against the theater scorned this sort of symbolic transference as a commonplace of dramatic "portraiture." Pierre Nicole's theory of spectatorship criticized the beholder's tendency to accept theatrical images as models of imitation, which gave life to a world of simulacra advantageous to political representation. The phantasmic force of the illusion of legitimacy fueled the system of art and politics in seventeenth-century France. (TM)
\end{abstract}

The Presence of the Sign in Goethe's Faust. NeIL M. FlaX . .

\begin{abstract}
Recent studies in the early history of semiotics allow us to trace an open concern with the problem of language in Goethe's Faust. The protagonist appears as a quest hero in search of a revelatory sign, whether verbal or pictorial, that will release him from the world of mediating representations. The folly of the quest is consistently satirized from the viewpoint of Romantic aesthetics and its theory of the symbol. For the Romantics, the aesthetic symbol is a sign that paradoxically effects a revelation by affirming its own semiotic nature. But in elevating semiotic phenomena to the status of epiphanies, Goethean symbolism in Faust confronts the same impasses that beset the hero as he seeks to escape the rule of signs. The recurring quandaries arise when the Romantic text responds to the initial challenge of semiotics by attempting to reconcile semiotics and theology. (NMF)
\end{abstract}

\section{At the Margin of Discourse: Footnotes in the Fictional Text.} Shari Benstock . . . . . . . . . .

Abstract. The referential and marginal features of footnotes serve different functions in criticism and literature: scholarly footnotes shore up the text by en- 
closing it and limiting its claims; in fiction, footnotes extend textual authority by enlarging the fictional context. Both inner- and outer-directed, these two kinds of notations display a self-conscious anxiety about the critical and creative acts they annotate. Scholarly notes mask this ambivalence by claiming extratextual authority; literary notes highlight the ambivalence by consciously dividing the text against itself. This essay examines the ways footnotes in Tom Jones, Tristram Shandy, and Finnegans Wake parody the notational convention and draw attention to the faulted authority of its discourse by flouting scholarly claims to objectivity and neutrality, by calling into question the relations of author and reader on textual grounds, and by using self-refiexive narrative methods to illustrate the rhetorical double bind that keeps all language at the margin of discourse. (SB)

\title{
Blake's Laocoön: A Degree Zero of Literary Production.
}

DAvid E. JAMES . . . . . . . . . .

\begin{abstract}
Blake's late engraving, erroneously known as The Laocoön, presents an unusually direct relation between the content of a literary work and the way the work is produced and consumed as an artifact. By restoring the statue's correct meaning ("Jah \& his two Sons Satan \& Adam"), Blake arrested its fall into materiality and application to "Natural Fact" and, in doing so, redeemed for spiritual purposes the engraving that he had begun as a commercial undertaking. In his commentary on the plate, he clarified for the first time the mutual exclusivity of art and commerce, not by making a materialist analysis, but by associating art with religion's traditional antipathy to money. He formulated a view of art as devotional practice rather than as the production of commodities, and this logic allowed the plate only the barest form of material existence. (DEJ)
\end{abstract}

\section{The Canterbury Tales and the Arabic Frame Tradition.}

Katharine SLATER GitTes.

\begin{abstract}
The Canterbury Tales is the culmination of a frame tradition that originated and developed in Arabia, not in the West. The Arabic practice of enclosing tales within a frame may be explained by principles of organization peculiar to medieval Arabic literature, art, music, and mathematics: a preference for concreteness, a stress on autonomous elements, and a reliance on external organizing devices. Most Arabic literature emphasizes the individual unit; frames remain open-ended and inconclusive and rarely determine the subject or form of any included part. Although many Western characteristics are present in medieval European frame narratives like the Disciplina Clericalis, the Decameron, and the Confessio Amantis, those works, nonetheless, reveal themselves as continuations of the Arabic tradition. Even the Canterbury Tales, with all its subtle artistry, retains qualities typical of its Arabic ancestors, notably the controlling travelpilgrimage motif, the pointedly random order of tales, and the prominent authorial personality. (KSG)
\end{abstract}

Forum . . . . . . . . . . . . . .

Forthcoming Meetings and Conferences of General Interest .

Professional Notes and Comment . . . . . . . . . 
PUBLICATIONS OF THE MODERN LANGUAGE ASSOCIATION OF AMERICA

Published Six Times a Year

Indexes: Vols. 1-50, 1935; 51-60, 1945; 51-79, 1964

JAMES M. CoX, 1983

Dartmouth College

EDITORIAL BOARD

\author{
NANCY K. MilleR, 1984 \\ Barnard College
}

Peter N. DunN, 1983

Wesleyan University

Elaine C. Showalter, 1983

Rutgers University

LAWRENCE I. LIPKING, 1984

Northwestern University

JURIJ STRIEDTER, 1983

Harvard University

Janet Adelman, 1986

University of California, Berkeley

JAIME ALAZRAKI, 1984

Harvard University

Nina Auerbach, 1983

University of Pennsylvania

Martin C. Batrestin, 1986

University of Virginia

SaCvan Bercovitch, 1983

Columbia University

LEO BRAUdY, 1983

Johns Hopkins University

VICTOR H. BROMBERT, 1983

Princeton University

Hanna K. Charney, 1984

Hunter College

City University of New York

RubY CoHN, 1986

University of California, Davis

\author{
ADVISORY COMMITTEE \\ Franco Fido, 1983 \\ Brown University \\ ERIC P. HAMP, 1983 \\ University of Chicago \\ IHAB HASSAN, 1983 \\ University of Wisconsin, \\ Milwaukee \\ Barbara E. JoHnson, 1986 \\ Yale University \\ ANNe G. JoNEs, 1986 \\ Allegheny College \\ WolfGang A. LePpManN, 1983 \\ University of Oregon
}

George L. Levine, 1984

Rutgers University

David H. Miles, 1983

University of Virginia

SidNEY MONAS, 1983

University of Texas, Austin

JANEL M. MUeLLER, 1985

University of Chicago
STEPHEN G. NICHOLS, JR., 1984

Dartmouth College

JAMES O. NAREMORE, 1986

Indiana University, Bloomington

Cary Nelson, 1986

University of Illinois, Urbana

Peter J. Rabinowitz, 1986 Hamilton College

WiNTHROP WeTHERBEE, 1986

University of Chicago

JoSEPH A. WITTREICH, JR., 1984

University of Maryland, College Park

Carl WoOdring, 1986

Columbia University

Ruth Bernard Yeazell, 1984

University of California,

Los Angeles

RUTH El SAFFar, 1985

University of Illinois, Chicago Circle

Editor: JoEl CONARROE

Editorial Supervisor: CLAIRE COOK

Managing Editor: JUDY GouLDING

Administrative and Editorial Assistant: MARGaret C. MEAD

\title{
A STATEMENT OF EDITORIAL POLICY
}

$P M L A$ welcomes essays of interest to those concerned with the study of language and literature. As the publication of a large and heterogeneous association, the journal is receptive to a variety of topics, whether general or specific, and to all scholarly methods and theoretical perspectives. The ideal $P M L A$ essay exemplifies the best of its kind, whatever the kind; addresses a significant problem; draws out clearly the implications of its findings; and engages the attention of its audience through a concise, readable presentation. Articles of fewer than 2,500 words or more than 12,500 words are not considered for publication. Translations should accompany foreign language quotations. The MLA urges its contributors to be sensitive to the social implications of language and to seek wording free of discriminatory overtones.

Only members of the Association may submit articles to PMLA. Each article submitted is sent to at least one consultant reader and one member of the Advisory Committee. Articles recommended by these readers are then sent to the members of the Editorial Board, who meet periodically with the Editor to make final decisions. Until a final decision is reached, the author's name is not made known to consultant readers, to members of the Advisory Committee and the Editorial Board, or to the Editor.

Submissions, prepared according to the $M L A$ Handbook for Writers of Research Papers, Theses, and Dissertations, should be addressed to the Editor of $P M L A, 62$ Fifth Avenue, New York, New York 10011. The author's name should not appear on the manuscript; instead, a cover sheet, with the author's name, address, and the title of the article, should accompany the article. Authors should not refer to themselves in the first person in the submitted text or notes if such references would identify them; any necessary references to the author's previous work, for example, should be in the third person. 